Article

\title{
Novel Technological and Management Options for Accelerating Transformational Changes in Rice and Livestock Systems ${ }^{\dagger}$
}

\author{
Ngonidzashe Chirinda ${ }^{1, *}$, Laura Arenas ${ }^{1}$, Sandra Loaiza ${ }^{1}$, Catalina Trujillo ${ }^{1}$, Maria Katto ${ }^{1}$, \\ Paula Chaparro ${ }^{1}$, Jonathan Nuñez ${ }^{1}$, Jacobo Arango ${ }^{1}$, Deissy Martinez-Baron ${ }^{2}$, \\ Ana María Loboguerrero ${ }^{2}$, Luis A. Becerra Lopez-Lavalle ${ }^{1}$, Ivan Avila ${ }^{3}$, Myriam Guzmán ${ }^{3}$, \\ Michael Peters ${ }^{1}$, Jennifer Twyman ${ }^{1}$, María García ${ }^{1}$, Laura Serna ${ }^{1}$, Daniel Escobar ${ }^{1}$, \\ Diksha Arora ${ }^{1}$, Jeimar Tapasco ${ }^{1}$, Lady Mazabel ${ }^{1}$, Fernando Correa ${ }^{1}$, Manabu Ishitani ${ }^{1}$, \\ Mayesse Da Silva ${ }^{1}$, Eduardo Graterol ${ }^{4}$, Santiago Jaramillo ${ }^{4}$, Adriana Pinto ${ }^{5}$, Andres Zuluaga ${ }^{6}$, \\ Nelson Lozano ${ }^{7}$, Ryan Byrnes ${ }^{8}$, Gabriel LaHue ${ }^{8}$, Carolina Alvarez ${ }^{9}$ (D), Idupulapati Rao ${ }^{1, \ddagger}$ \\ and Rolando Barahona ${ }^{10}$
}

1 Centro Internacional de Agricultura Tropical (CIAT), Apartado Aéreo 6713, Palmira, Colombia; eelnac@leeds.ac.uk (L.A.); s.p.loaiza@cgiar.org (S.L.); c.trujillo@cgiar.org (C.T.); M.Katto@CGIAR.ORG (M.K.); paulini87@hotmail.com (P.C.); np.jonathan@gmail.com (J.N.); j.arango@cgiar.org (J.A.); 1.a.becerra@cgiar.org (L.A.B.L.-L.); m.peters-ciat@cgiar.org (M.P.); j.twyman@cgiar.org (J.Tw.); maria.garcia@cgiar.org (Ma.G.); l.p.serna@cgiar.org (L.S.); d.escobar@cgiar.org (D.E.); d.arora@cgiar.org (D.A.); j.tapasco@cgiar.org (J.Ta.); l.j.mazabel@cgiar.org (L.M.); f.correa@cgiar.org (F.C.); m.ishitani@cgiar.org (M.I.); m.a.dasilva@cgiar.org (M.D.S.); rao.idupulapati@ars.usda.gov (I.R.)

2 CGIAR Research Program on Climate Change, Agriculture and Food Security (CCAFS), Apartado Aéreo 6713, Palmira, Colombia; d.m.baron@cgiar.org (D.M.-B.); a.m.loboguerrero@cgiar.org (A.M.L.)

3 Federación Nacional de Arroceros (FEDEARROZ), 500001 Villavicencio, Colombia; ivanavila@fedearroz.com.co (I.A.); patriciaguzman@fedearroz.com.co (My.G.)

4 Fondo Latinoamericano para Arroz de Riego (FLAR), Apartado Aéreo 6713, Palmira, Colombia; e.j.graterol@cgiar.org (E.G.); s.jaramillo@cgiar.org (S.J.)

5 Ministerio de Ambiente y Desarrollo Sostenible (MADS), 111711 Bogotá, Colombia; apintobr@gmail.com

6 Federación Colombiana de Ganaderos (FEDEGAN), 111711 Bogotá, Colombia; andres.zuluaga@javeriana.edu.co

7 Ministerio de Agricultura y Desarrollo Rural (MADR), 111711 Bogotá, Colombia; nelson.lozano@minagricultura.gov.co

8 Department of Plant Sciences, University of California, Davis, CA 95616, USA; rbyrnes@ucdavis.edu (Ry.B.); gtlahue@ucdavis.edu (G.L.)

9 Instituto Nacional de Tecnología Agropecuaria (INTA), 1000 Buenos Aires, Argentina; alvarez.carolina@inta.gob.ar

10 Universidad Nacional de Colombia (UNAL), 050001 Medellín, Colombia; rbarahonar@unal.edu.co

* Correspondence: n.chirinda@cgiar.org; Tel.: +57-24450001

+ This paper appear on the 23rd International Sustainable Development Research Society Conference, Bogota, Colombia, 14-16 June 2017.

$\ddagger$ Present address: Plant Polymer Research Unit, National Center for Agricultural Utilization Research, Agricultural Research Service, United States Department of Agriculture, 1815 North University Street, Peoria, IL 61604, USA

Received: 15 September 2017; Accepted: 17 October 2017; Published: 27 October 2017

Abstract: Agricultural producers grapple with low farm yields and declining ecosystem services within their landscapes. In several instances, agricultural production systems may be considered largely unsustainable in socioeconomic and ecological (resource conservation and use and impact on nature) terms. Novel technological and management options that can serve as vehicles to promote the provision of multiple benefits, including the improvement of smallholder livelihoods, are needed. 
We call for a paradigm shift to allow designing and implementing agricultural systems that are not only efficient (serving as a means to promote development based on the concept of creating more goods and services while using fewer resources and creating less waste) but can also be considered synergistic (symbiotic relationship between socio-ecological systems) by simultaneously contributing to major objectives of economic, ecological, and social (equity) improvement of agro-ecosystems. These transformations require strategic approaches that are supported by participatory system-level research, experimentation, and innovation. Using data from several studies, we here provide evidence for technological and management options that could be optimized, promoted, and adopted to enable agricultural systems to be efficient, effective, and, indeed, sustainable. Specifically, we present results from a study conducted in Colombia, which demonstrated that, in rice systems, improved water management practices such as Alternate Wetting and Drying (AWD) reduce methane emissions $(\sim 70 \%)$. We also show how women can play a key role in AWD adoption. For livestock systems, we present in vitro evidence showing that the use of alternative feed options such as cassava leaves contributes to livestock feed supplementation and could represent a cost-effective approach for reducing enteric methane emissions (22\% to 55\%). We argue that to design and benefit from sustainable agricultural systems, there is a need for better targeting of interventions that are co-designed, co-evaluated, and co-promoted, with farmers as allies of transformational change (as done in the climate-smart villages), not as recipients of external knowledge. Moreover, for inclusive sustainability that harnesses existing knowledge and influences decision-making processes across scales, there is a need for constant, efficient, effective, and real trans-disciplinary communication and collaboration.

Keywords: rice; livestock; cassava leaves; forage; greenhouse gases

\section{Introduction}

To address the challenges faced by farmers in Latin America (LAC), the International Center for Tropical Agriculture (CIAT) and its partners are currently working within the framework of climate smart agriculture (CSA). The CSA approach is defined as agriculture that (a) sustainably increases agricultural productivity and incomes; (b) improves adaptation and builds farmer resilience to climate change; and (c) reduces and/or removes greenhouses gases (GHG) emissions where possible [1]. The process of scaling CSA builds on a theory presented by Lipper et al. [2], who propose four key types of partnerships for change, which include: (a) implementing partners and local organizations to build science-based evidence; (b) climate risk management service providers and National Agricultural Research and Extension Systems to explore possibilities to strengthen institutions and services through better use of climate information; (c) policy partners to gain insights for improved agricultural policy and governance; and (d) large agencies and companies driving implementation to understand the opportunities and possibilities for stable and strategic investments. The objectives of this study included (a) improving our understanding of the socioeconomic context for CSA adoption, with a strong emphasis on gender dynamics in rice and cattle production systems; (b) evaluating the potential of two CSA options to reduce $\mathrm{CH}_{4}$ emissions along the rice and cattle supply chains; (c) exploring the utility of a pro-poor digital soil mapping (DSM) tool; and (d) discussing the possibility of farmers, researchers, and other stakeholders working as allies of transformational change using the Climate-Smart Villages (CSV) approach.

Consideration of the socioeconomic and cultural aspects is important as it leads to better understanding of how social differentiation can affect or influence the adoption of CSA options and how the CSA options may impact farmer relationships. For example, in most farming communities, women have different needs, preferences, constraints, and responsibilities compared to men Huyer et al. [3], in part, due to the gendered roles and the inequalities in accessing and controlling key agricultural 
resources [4]. Therefore, understanding the intra-household allocation of productive resources and gender-based constraints to adoption of CSA options is crucial for scaling. Additionally, for the assessment of men and women farmers' needs, researchers and development practitioners must examine how the introduction of a CSA option may increase or decrease the labor requirements of men and women farmers in different agricultural sectors [5].

In the cattle sector, CIAT and its partners are promoting the concept of LivestockPlus. The LivestockPlus concept is based on three interrelated intensification processes namely, genetic intensification, which is the utilization of superior and well-managed forage grass and legume cultivars for increased livestock productivity; ecological intensification, which is the adoption of improved farm and natural resource management practices; and socio-economic intensification, which is the enhancement of institutions and policies, enabling technological changes and supporting their use [6]. To operationalize this concept, technological, management, policy, and cultural changes are needed at several stages along the cattle value chain. Technological options that have been promoted in the past include tropical forage grasses such as Brachiaria humidicola that contribute to increased cattle production [7], carbon sequestration [8], and a reduction in nitrogen fertilizer use and urine-based nitrous oxide $\left(\mathrm{N}_{2} \mathrm{O}\right)$ emissions $[9,10]$. As enteric fermentation represents the largest anthropogenic source of $\mathrm{CH}_{4}$, an indicator of feed inefficiency [11], there is an urgent need for disruptive CSA options that improve feed utilization and, consequently, mitigate $\mathrm{CH}_{4}$ emissions.

In the rice sector, a consortium, including CIAT, the National Federation of Rice Producers (FEDEARROZ), the Latin American Fund for Irrigated Rice (FLAR), the Ministry of Agriculture and Rural Development (MADR), and the support of the Ministry of Environment and Sustainable Development (MADS), is proposing options to reduce GHG emissions from the rice supply chain through more efficient water management practices within the Massive Adoption of Technology (AMTEC) programme. The AMTEC programme's main goal is to transfer all available advanced soil and crop management and technological options to increase productivity and reduce production costs within a period of five years with a minimum environmental impact [12]. Within the AMTEC programme, the rice consortium presupposes that the adoption of improved water management practices will be based on four key pillars: (a) increased farmer awareness, (b) improved water distribution systems, (c) on-farm control of water resources, and (d) identification of incentives for water savings.

Alternate Wetting and Drying (AWD) is a management strategy characterized by an intermittent irrigation schedule that alternates flooded and non-flooded conditions. This practice can reduce water inputs (and possibly irrigation costs) and lower methane $\left(\mathrm{CH}_{4}\right)$ emissions, as aerobic conditions largely eliminate the activity of methanogenic bacteria [13]. Since water management practices within the AMTEC programme share similarities with AWD, the promotion of the latter in Colombia can be done through merging the two practices to develop a more advanced best-fit water management practice that takes into consideration the prevailing socioeconomic and biophysical conditions.

Soil types and properties vary across landscapes and thus function differently depending on their biophysical properties and applied management. Understanding soil variability is critical for improving the targeting of management and technological options that enhance crop and livestock productivity and promote the efficient use of costly inputs such as fertilizers. However, due to the large quantity of soil data required to develop high resolution maps and the associated laboratory costs, accurate soil mapping efforts are normally beyond the reach of small farmers. Access to recent innovations has allowed soil experts to integrate current technologies (e.g., satellite images, digital elevation models) with soil data in order to provide continuous soil property maps at high resolutions that allow decisions at the local and/or regional level [14]. Digital soil maps (DSM) provide detailed, site-specific information that informs management and technological choices for improving efficiency in resource use and conservation.

In the cattle sector, we take the forage research a step further and explore the possibility of reducing enteric methane emissions through the use of cattle diets that include Brachiaria humidicola (a tropical grasses) in combination with cassava (Manihot esculenta) leaves. For rice production systems, 
we present the first results of field measurements, comparing methane emissions from flooding and AWD in Colombia. We also provide evidence on the utility of a Pro-Poor DSM approach, which uses the available information combined with less intensive field sampling, to cost-effectively generate continuous soil maps at a high resolution. We also discuss how lessons learnt in the Climate-Smart Villages (CSV) initiated by the Consultative Group on International Agricultural Research (CGIAR) Research Program on Climate Change, Agriculture, and Food Security (CCAFS) can be harnessed to create platforms, where farmers, researchers, and other stakeholders can work together as allies of change [15].

\section{Methodology}

\subsection{Rice Systems}

\subsubsection{Gender Dynamics}

During March and April 2016, a farm household survey, which included 609 households, was conducted in five rice producing departments of Colombia (Tolima, Norte de Santander, Córdoba, Cesar, and Casanare). The sample size represented $10 \%$ of the total number of farmers with irrigated rice, which was determined through the National Rice Census of 2006, conducted by FEDEARROZ. A sex-disaggregated research instrument was used to collect information on decision-making, labor, and access to key resources, as well as limitations and incentives for the implementation of CSA options such as AWD.

\subsubsection{Monitoring $\mathrm{CH}_{4}$ and $\mathrm{N}_{2} \mathrm{O}$ Fluxes in Rice Fields under $\mathrm{AWD}$ and Continuous Flooding}

A field study was conducted at the FEDEARROZ Experimental Station "Las Lagunas" in Saldaña, Tolima ( $3^{\circ} 54^{\prime} 47.45^{\prime \prime} \mathrm{N}, 74^{\circ} 59^{\prime} 8.47^{\prime \prime} \mathrm{W}$, elevation: 350 m.a.s.l) during two cropping seasons (June to September 2015, and March to June 2016). The study region has a mean air temperature, annual precipitation, and relative humidity of $28{ }^{\circ} \mathrm{C}, 1541 \mathrm{~mm}$, and $70 \%$, respectively. The soil order at the experimental station is Inceptisol and has a sandy-loam texture with a bulk density of $1.6 \mathrm{~g} \mathrm{~cm}^{-3}$, a $\mathrm{pH}$ of about 5.3 , and an organic matter (OM) content of $1.4 \%$.

The experiment was designed under the framework of technology transfer and cooperation between the Science and Technology Research Partnership for Sustainable Development (SATREPS) and FEDEARROZ. The experiment had a randomized block design, with three replicates per treatment. The GHG evaluation was conducted on two water management treatments (continuous flooding and AWD) that differed in the number of irrigation and drain events. During the 2015 cropping season, the continuous flooding (CF) treatment was irrigated 24 times, while the AWD treatment was irrigated 17 times. During the wetter year (2016), the CF treatment was irrigated 11 times, while the AWD treatment was irrigated five times. The cumulative rainfall during the growing season was lower in 2015 (10 mm) compared to 2016 (223 mm). We used the commercial variety FEDEARROZ-60, which was planted using direct seeding, as a test crop. In addition, the plots we used were fertilized with nitrogen at a rate of $180 \mathrm{~kg} \mathrm{~N} \mathrm{ha}^{-1}$, which was split in doses of 27, 45, 45, 36, and $27 \mathrm{~kg}$ at 12, 25, 35, 50, and 65 days after plant emergence.

Gas measurements during the first cropping season were conducted during the period from 5 June to 24 September 2015 and during the period from 10 March to 17 June 2016 for the second cropping season. During both measurement campaigns, gas sampling was initially aligned to fertilization, with measurements being conducted one day before fertilization and for two consecutive days post-fertilization. After the fertilization period, measurements were conducted weekly until harvest. All samples were taken in the morning (8:00 to 11:00 a.m.). The method used for gas sampling was the static-closed chamber technique. Specifically, plastic buckets (114 L in volume and $80 \mathrm{~cm}$ height) were used in combination with custom-made chamber bases $(40 \mathrm{~cm}$ height) that included a canal, which made it possible to have a water seal during chamber deployment. Vents were installed in 
the static chambers to avoid the creation of pressure differences between the inside and outside of the chamber during chamber deployment. A fan was also installed inside the chamber to ensure the mixing of air within the chamber and that, at any given time, the sample $(20 \mathrm{~mL})$, collected using a syringe and stored in a pre-evacuated vial, was representative of the air inside the chamber.

The methane and $\mathrm{N}_{2} \mathrm{O}$ concentrations in the collected vials was analyzed by gas chromatography (Shimadzu GC-2014). The fluxes of each gas were calculated using a gas concentration rate and sampling time (45 $\mathrm{min}$ ) in combination with the ideal gas equation. The cumulative fluxes for the monitoring period were calculated using linear interpolation.

\subsection{Cattle Systems}

\subsubsection{Gender Dynamics}

The analysis of gender relations within the livestock sector was based on two exploratory studies conducted along the cattle supply chain [16]. These studies were used to gain insights into the roles played by men and women in livestock production. In addition, the studies are used to predict the potential impacts of climate change and the introduction of cassava leaves into cattle diets on the workload of men and women in small-scale livestock producing households.

\subsubsection{In Vitro Experiment on Cattle Diets with Cassava Supplements}

An experiment organized as a completely randomized design with three batch replicates per treatment was conducted using different combinations of swards of Brachiaria humidicola (BH) and cassava leaves from six genotypes (ME1 to ME5 and MP6) in different proportions: $100 \% \mathrm{BH}, 50 \%$ ME1 to ME5 and MP6 (Cassava) + 50\% BH, and 100\% Cassava (ME1 to ME5 and MP6), giving a total of thirteen treatments. The genotypes of ME were COL 22 (ME1), BRA 12 (ME2), COL 1468 (ME3), COL 2246 (ME4), PER 239 (ME5), and PSE (MP6). The nutritional quality of the different combinations was determined according to the methods of the International Organization for Standardization. The neutral detergent fiber (NDF) was determined following the method described by Van Soest et al. [17] with acid detergent fiber (ADF), according to Association of Official Analytical Chemists (AOAC) 973.18 (2010); the ash content was determined through direct incineration in a muffle furnace [18].

The in vitro gas production technique was conducted according to the methodology suggested by Theodorou et al. [19]. Specifically, $1 \mathrm{~g}$ of samples, including leaves of $\mathrm{BH}$ and mixtures of $\mathrm{BH}$ with cassava leaves from six genotypes, were incubated in $160 \mathrm{~mL}$ glass flasks with $85 \mathrm{~mL}$ of buffer solution, $10 \mathrm{~mL}$ of strained rumen fluid, obtained from two donor animals, and $4 \mathrm{~mL}$ of a reductor solution [19]. The bottles were hermetically sealed and maintained in a bath at $39^{\circ} \mathrm{C}$. Over $96 \mathrm{~h}$, the samples were incubated, and readings of volume $(\mathrm{V})$ and pressure (psi) were taken using a pressure transducer (Sper Scientific, Scottsdale, AZ, USA) at nine different incubation times: three, six, nine, 12, 24, 36, 48, 72 , and $96 \mathrm{~h}$.

\subsection{Soil Information for Better Targeting and Resource Use Efficiency}

A pilot area in the Tolima Department of Colombia was chosen for the calibration and validation of the Digital Soil Mapping (DSM) approach. The study was conducted over a rice growing area of $4640 \mathrm{~km}^{2}$ located between the latitudes $3^{\circ} 40^{\prime} 0^{\prime \prime} \mathrm{N}$ and $5^{\circ} 0^{\prime} 0^{\prime \prime} \mathrm{N}$ and the longitudes $75^{\circ} 14^{\prime} 0^{\prime \prime} \mathrm{W}$ and $74^{\circ} 42^{\prime} 0^{\prime \prime} \mathrm{W}$, which includes Norte-Meseta, Saldaña, and Ortega in Colombia. The average annual precipitation in this region is 1500 to $2000 \mathrm{~mm}$, and the average annual temperature is $24^{\circ} \mathrm{C}$. The study area has an elevation varying from 219 to 1662 m.a.s.l., and the main soil orders are Alfisols, Entisols, and Inceptisols [20].

Two data sets were used for mapping continuous property maps for the study area: (1) GIS data: a digital elevation model (DEM) SRTM of $90 \mathrm{~m}$ and a soil class polygon map at a scale of 1:500,000 from Instituto Agustín Codazzi (IGAC) and (2) field data: 90 soil samples collected from 30 sites, with 
three replicates each, from 0 to $20 \mathrm{~cm}$. The collected samples were characterized for $\mathrm{pH}$, organic matter $(\mathrm{OM})$, and sand and clay content.

To develop the DSM model, landscape units were defined for the study area by combining soil class maps from IGAC with a landform map generated by the DEM. Landform classification was performed using the Geomorphons add-on in Grass-GIS, which segregates the landscape into the 10 common landform elements: flat, peak, ridge, shoulder, spur, slope, pit, valley, foot slope, and hollow [21]. Soil maps of $\mathrm{pH}, \mathrm{OM}$, clay, and sand at $90 \mathrm{~m}$ resolution were then generated using a fuzzy logic approach in the Soil Land Inference Model [22]. Class threshold values were determined statistically from the distribution of the Wetness Index (WI), the normalized height, and the percent slope within each soil unit in combination with $80 \%$ of the field data.

\subsection{Climate-Smart Village Approach in Colombia}

The CSV approach is an agricultural research-for-development approach that enables dialogue between communities of farmers, scientists, extensionists, and development practitioners towards learning and developing context-specific options that support short and long-term adaptation to climate changes while reducing impacts on the environment (e.g., GHG emissions) and increasing productivity, thus addressing the three pillars of CSA [1]. In Colombia, a CSV is located to the northwest of Popayán, the capital city of the Cauca Department. Farmers in this locality such as others in LAC face several challenges related to climate variability, limited resource availability, and soil degradation, which are affecting the productivity of their crops and livestock systems and thus their quality of life [15].

\section{Data Analyses}

To analyze the gender data in rice systems, we conducted a descriptive analysis based on attempting to answer the following key questions: (a) Who, within or outside the household, made decisions about rice production? (b) Which households have access to the key resources required for the implementation of improved water management? (c) Are there economic or noneconomic incentives for improved water management? (d) Which labor activities are conducted by men or by women? In order to answer questions b and c, we used a Chi Square test to calculate the association between incentives for AWD and the types of households. It was not possible to obtain information from women's' and men's' perspectives in the same proportion since only $9 \%$ of the respondents were women. Therefore, for our analyses, we used the men's perspective on the gender dynamics as well. Even though we assume that the information provided by men underestimates women's actual participation, the data collected are useful since they provide information about women's and men's roles along the rice production chain.

With respect to gas analysis in rice and cattle systems, the differences in cumulative $\mathrm{CH}_{4}$ and $\mathrm{N}_{2} \mathrm{O}$ emissions between treatments and years were determined through an analysis of variance (ANOVA) conducted using the R software [23].

The fermentation dynamics and ruminal nutrient degradation in the in vitro experiment on cattle with cassava supplements were assessed by the gas (pressure) transducer technique, as described by Theodorou et al. [19], and the differences between means were tested using the Tukey mean comparison test $(p<0.05)$ [24].

The validation of the Digital Soil Mapping (DSM) model was performed using $20 \%$ of the field data not used for model calibration in the pilot area in Tolima, Colombia. The Root Mean Square Error Normalized (RMSEn) by the data total variability was used to validate and assess the model accuracy. RMSEn values are expressed as percentages, and lower values indicate less residual variance and present good accuracy, indicating that the model is appropriate to develop soil property maps for the local conditions.

A discussion on the utility of the Climate-smart village (CSV) approach for grounding research in appropriate and location/context-specific enabling conditions is also included. 


\section{Results and Discussion}

We discuss here our findings on the different aspects and also include a discussion of our perspective on what these results mean for improving the sustainability of agricultural systems.

\subsection{Socio-Economic and Gender Aspects}

\subsubsection{Rice Systems}

Within the rice growing households, about $38 \%$ of the respondents indicated that both women and men participate in decision-making. However, it is unambiguous that women are generally not recognized as the principal decision-makers since only $8 \%$ of the respondents identified them as such. Whereas, in the majority of cases, women respondents recognized themselves as principal decision-makers, there were few cases in which men recognized women as being the main decision-makers. It is probably prudent to assume the prevalence of a gender bias that depended on the sex of the respondent [25]. Therefore, as women are not generally recognized as decision-makers from the men's perspective, it is also probable that their needs and preferences may not be adequately considered when deciding on the adoption of CSA options. It is therefore possible that, without an understanding of these dynamics, adopted technological and management practices may increase the burden on women and thus increase their time poverty [26].

According to the given responses, rice producers in the five rice-growing departments of Colombia have control over the amount of water they receive (93\%) and affirm having leveled their plots $(88 \%)$, yet several of the respondents $(44 \%)$ indicated that they face water availability challenges. Paradoxically, it seems that, bar challenges related to water availability (particularly during the drier years), there may currently be no economic incentives to save water, as farmers do not pay for water based on the volume of water they use but based on the area of land they own. To promote water savings, there may be a need to change the pricing mechanism to reflect usage, though care must be taken to avoid increases in water prices that would be detrimental to farmer welfare. This is particularly important for the scaling of CSA options such as AWD. Surprisingly, our results show that households that have women producers had a higher propensity towards more non-economic incentives (interest in GHG mitigation and reducing water use) to save water (Figure 1). However, while the available information does not adequately explain why households in which women participate are more likely to be motivated by GHG mitigation and water savings, Figueiredo and Perkins [27] suggest that this might be explained by the historically gendered roles that associate women with more caring attributes.

It is also clear from our results that women participate in the rice supply chain as hired labor for specific manual activities such as manual weed control [28]. If management practices such as AWD impact the time needed for performing agricultural activities, especially manual weed control, it could reduce or increase the time used by rural women workers.

\subsubsection{Cattle Systems}

An exploratory qualitative study was conducted in the Cauca region of Colombia. The study included two focus group discussions, held separately with men and women livestock producers. The main objective of the study was to understand what the direct roles played by men and by women are in livestock production and how they support the production through indirect contributions.

Contrary to what is perceived in the literature, women play an active role in livestock production in Colombia. The women in this region perform a wide range of activities like the management of pastures, caring for animals, helping in the process of curing animal products such as meat and hides, milking, processing milk products, and the selling of livestock products. In addition, women perform all the household chores and care work that indirectly supports the productive efforts of the men in the livestock sector. The idea of this study is to examine the potential impacts of CSA options on the workload of men and women. For example, based on the cassava experiment, there is a potential 
to introduce a sustainable feed, especially during the dry season. However, it is crucial that we assess who is involved in the production and processing of cassava leaves.

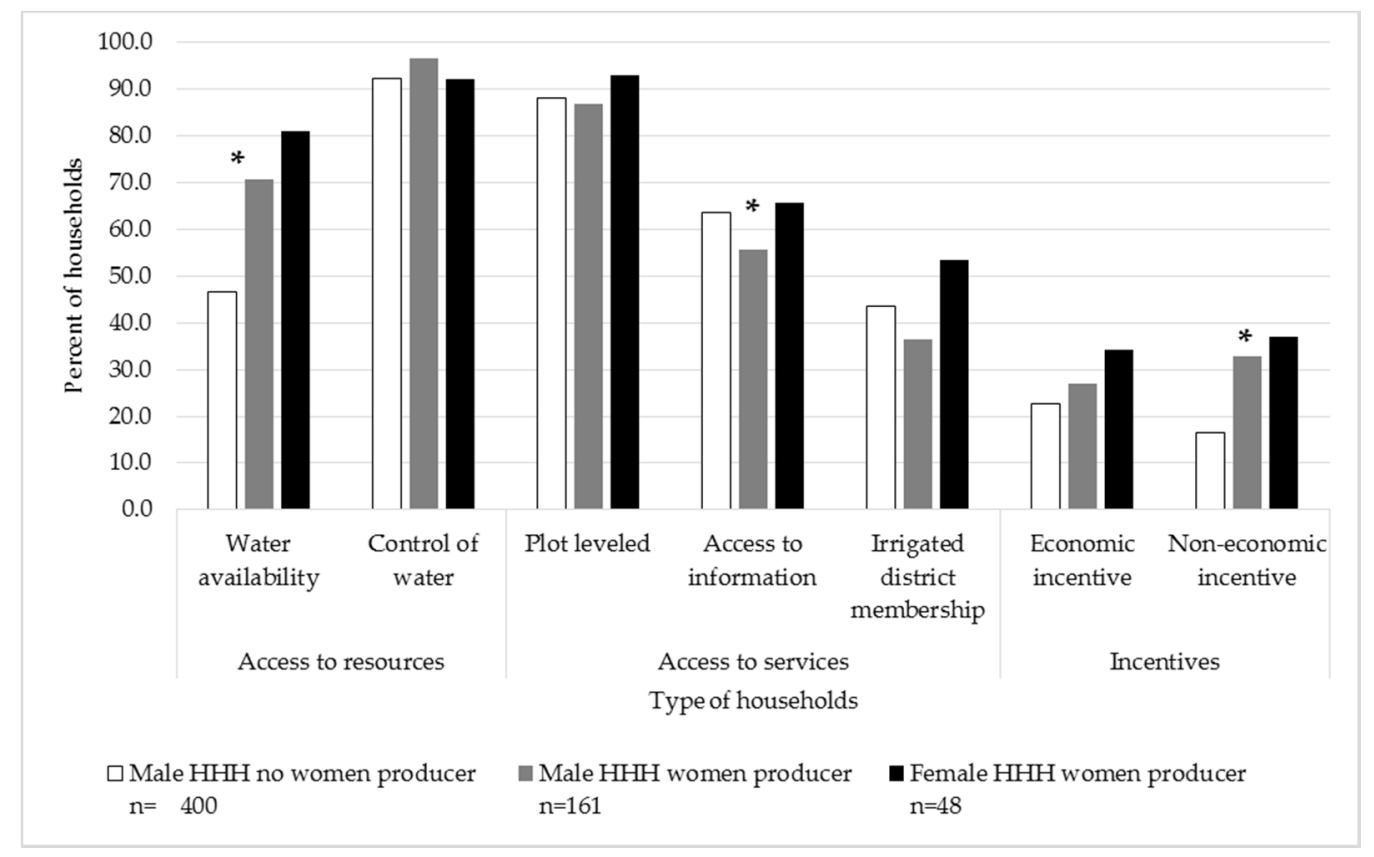

Figure 1. Differences in access to key resources and incentives to implement Alternate Wetting and Drying (AWD) among types of households (male and female headed households $(\mathrm{HHH})$ and in which there are women producers involved in decision making and ownership of land/machinery). Source: [28]. * Statistically different at a 5\% level of significance.

\subsection{Potential of CSA Options to Reduce GHG Emissions}

\subsubsection{Monitoring GHG Emissions in Irrigated Rice Systems}

In 2015, the cumulative $\mathrm{CH}_{4}$ emissions from flooded rice and AWD were 7.54 and $2.28 \mathrm{~kg} \mathrm{CH}_{4}$ ha $^{-1}$ season $^{-1}$, respectively, which represented a significant reduction $(69 \%)$ of $\mathrm{CH}_{4}$ emissions with AWD. Similarly, in 2016, cumulative $\mathrm{CH}_{4}$ emissions from flooded rice plots were significantly higher (19.50 $\mathrm{kg} \mathrm{CH}_{4} \mathrm{ha}^{-1}$ season $^{-1}$ ) than those observed in the AWD $\left(5.28 \mathrm{~kg} \mathrm{CH}_{4}\right.$ ha $^{-1}$ season $^{-1}$ ) plots (Figure 2a). While there were significant differences in the $\mathrm{N}_{2} \mathrm{O}$ emissions observed in 2015 compared to those observed in 2016, the soil $\mathrm{N}_{2} \mathrm{O}$ emissions observed during the drier year (2015) were higher in the AWD (1.53 $\left.\mathrm{kg} \mathrm{N}_{2} \mathrm{O} \mathrm{ha}{ }^{-1}\right)$ than in the continuously flooded $\left(0.56 \mathrm{~kg} \mathrm{~N}_{2} \mathrm{O} \mathrm{ha}^{-1}\right)$ plots, but in both years the treatment differences were not significant at a $5 \%$ level of significance. This finding corroborates those of Linquist et al. [29], who also report no significant difference in N2O emissions between $\mathrm{CF}$ and $\mathrm{AWD}$ for rice-rice rotation systems. The $\mathrm{CH}_{4}$ emissions in the continuous flooded plots were generally significantly lower than those estimated using the global average estimated through a meta-analysis (134 $\mathrm{kg} \mathrm{CH}_{4} \mathrm{ha}^{-1}$ season $^{-1}$ ) conducted by Linquist et al. [30]. However, the observed emissions were within the range reported in several previous studies [31,32]. The low methane emissions may be due to a combination of factors, including low soil $\mathrm{pH}$, coarse-textured soil [33], and low soil organic matter [31].

The cumulative $\mathrm{CH}_{4}$ emissions in the continuously flooded and AWD treatments were significantly different within $(p<0.001)$ and between cropping seasons $(p<0.05)$, with the latter result probably being due to variations in weather conditions between the two cropping seasons. The percent reductions in $\mathrm{CH}_{4}$ emissions were similar to those observed by Thawda et al. [34] and Katayanagi et al. [35], who also reported high $\mathrm{CH}_{4}$ emission reductions with AWD (65 to $73 \%$ ). Our results show that, compared to continuous flooding, water management strategies such as AWD have 
mitigation benefits under both El Niño and La Niña conditions. However, AWD showed a higher $\mathrm{CH}_{4}$ mitigation potential under the wetter El Niño conditions, which is possibly due to the fact that during the drier year (the first monitoring period), there were challenges to maintaining continuously flooded conditions due to limited water availability. Therefore the continuously flooded treatment was not flooded during the whole monitoring period, which may explain the high variation in soil $\mathrm{N}_{2} \mathrm{O}$ emissions. As the difficulty of maintaining floodwater in dry years is typical for conventional farmer management in the study region, these findings are relevant to local production systems.

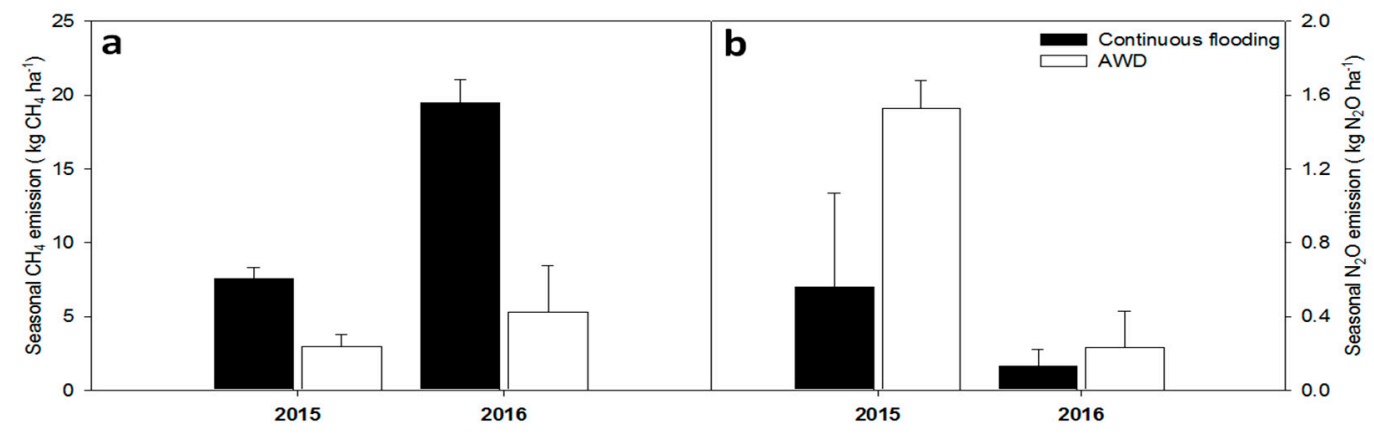

Figure 2. (a) Methane and (b) nitrous oxide emissions from soils under continuous flooding and subjected to Alternate Wetting and Drying (AWD).

Compared to AWD, the continuous flooded (CF) plots had a higher global warming potential (GWP) over a 100 year time horizon [36] in 2016. In contrast, in 2015, the AWD showed a higher but non-significant difference in GWP, compared to CF (Table 1).

Table 1. Global Warming Potentials (GWP) and Greenhouse Gas (GHG) emissions in a rice system subjected to continuous flooding (CF) and Alternate Wetting and Drying (AWD) water management systems.

\begin{tabular}{ccccc}
\hline \multirow{2}{*}{ GHG Emissions and GWP } & \multicolumn{2}{c}{2015} & \multicolumn{2}{c}{2016} \\
\cline { 2 - 5 } & CF & AWD & CF & AWD \\
\hline Methane $\left(\mathrm{kg} \mathrm{CH}_{4} \mathrm{ha}^{-1}\right)$ & $7.54^{\mathrm{a}}$ & $2.28^{\mathrm{b}}$ & $19.5^{\mathrm{A}}$ & $5.28^{\mathrm{B}}$ \\
Nitrous oxide $\left(\mathrm{kg} \mathrm{N}_{2} \mathrm{O} \mathrm{ha} \mathrm{ha}^{-1}\right)$ & $0.56^{\mathrm{a}}$ & $1.53^{\mathrm{a}}$ & $0.23^{\mathrm{A}}$ & $0.13^{\mathrm{A}}$ \\
GWP $\left(\mathrm{kg} \mathrm{CO}_{2}\right.$ equivalents ha & & & & \\
\end{tabular}

For methane and nitrous oxide emissions and global warming potentials (column 1), comparisons for each year are made between CF and AWD. In each year, the values in each row that are followed by the same letter are not significantly different at $p<0.05$.

While there were no significant trade-offs between $\mathrm{CH}_{4}$ and $\mathrm{N}_{2} \mathrm{O}$, the high inter-annual variation in $\mathrm{N}_{2} \mathrm{O}$ emissions reflects the key role that $\mathrm{N}_{2} \mathrm{O}$ could have, particularly during dry periods, and the importance of determining a conservative way to implement AWD without significantly increasing $\mathrm{N}_{2} \mathrm{O}$ emissions, which have a global warming potential approximately 12 times greater than $\mathrm{CH}_{4}$.

\subsubsection{In Vitro Experiment on Cattle Diets with Cassava Supplements}

The results in Figure 3 indicate that the $\mathrm{CH}_{4}$ emissions from the $100 \% \mathrm{BH}$ treatment were significantly different $(p<0.001)$ from those from all the $100 \%$ cassava leaves treatments. This result is not surprising as the higher tannin content in cassava leaves than in BH swards (Table 2) probably reduced the methanogen activity, as reported in previous studies [37]. Secondary compounds such as tannins have been reported to either target methanogen activity or disrupt the commensal relationship between methanogens and other microbes such as protozoa populations and fungi [26,38]. Thus tannins reduce gas production by reducing fiber digestion [39]. In addition, Kume [40] reported a reduction in $\mathrm{CH}_{4}$ production when the NDF content is low, which may also explain the lower $\mathrm{CH}_{4}$ 
production in treatments of $100 \%$ cassava leaves (NDF: 47\%) compared to $100 \% \mathrm{BH}$ swards (NDF: $71.2 \%)$. Other studies [41,42] have also reported that high concentrations of NDF in forages cause an increase of $\mathrm{CH}_{4}$ production, due to a shift in the proportion of short chain volatile fatty acids towards acetate, which produces more $\mathrm{H}_{2}$. However, though showing a tendency for lower $\mathrm{CH}_{4}$ production than in the $100 \% \mathrm{BH}$ treatment, mixtures of cassava leaves and $\mathrm{BH}$ swards did not result in significantly lower $\mathrm{CH}_{4}$ production in all but one cassava genotype $(\mathrm{BH}+\mathrm{ME} 4)$.

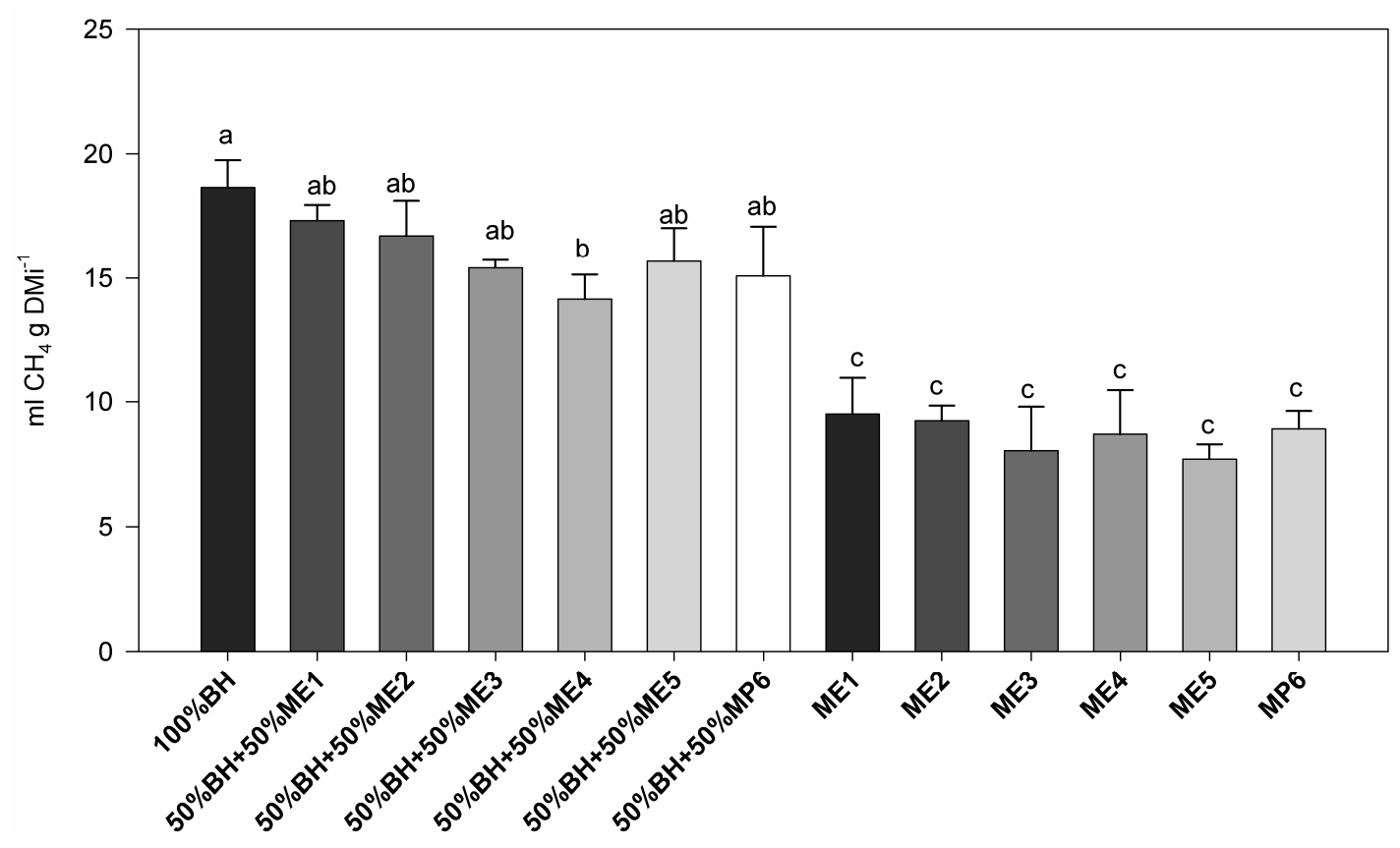

Figure 3. $\mathrm{CH}_{4}$ emissions $\left(\mathrm{mL} \mathrm{CH}_{4} \mathrm{~g} \mathrm{DMi}^{-1}\right)$ from an in vitro assay conducted with Brachiaria humidicola $(\mathrm{BH})$ and different cassava (ME) and $\mathrm{BH}$ mixtures.

Table 2. Chemical compositions of the treatments utilized for the in vitro experiment on cattle diets.

\begin{tabular}{|c|c|c|c|c|c|c|c|c|}
\hline Treatment & $\begin{array}{l}\text { DM } \\
(\%)\end{array}$ & $\begin{array}{l}\text { OM } \\
(\%)\end{array}$ & $\begin{array}{c}A \\
(\%)\end{array}$ & $\begin{array}{l}\text { NDF } \\
(\%)\end{array}$ & $\begin{array}{l}\text { ADF } \\
(\%)\end{array}$ & $\begin{array}{l}\text { DIVDM } \\
(\%)\end{array}$ & $\begin{array}{c}\text { Total Tannins } \\
(\%)\end{array}$ & $\begin{array}{c}\text { Total Phenol } \\
\text { (\%) }\end{array}$ \\
\hline $100 \% \mathrm{BH}$ & 96.8 & 91.4 & 8.6 & 71.2 & 37.2 & 60.8 & 0.87 & 1.35 \\
\hline $50 \%$ BH + 50\% ME1 & 96.2 & 89.0 & 11.0 & 57.3 & 30.4 & 63.5 & - & - \\
\hline $50 \%$ BH + 50\% ME2 & 96.6 & 89.7 & 10.3 & 58.6 & 33.4 & 61.3 & - & - \\
\hline $50 \%$ BH + 50\% ME3 & 96.3 & 89.8 & 10.2 & 57.7 & 32.1 & 62.7 & - & - \\
\hline $50 \% \mathrm{BH}+50 \% \mathrm{ME} 4$ & 96.3 & 87.9 & 12.1 & 58.1 & 31.4 & 62.0 & - & - \\
\hline $50 \%$ BH + 50\% ME5 & 95.8 & 89.6 & 10.4 & 60.8 & 32.2 & 61.2 & - & - \\
\hline $50 \% \mathrm{BH}+50 \% \mathrm{MP} 6$ & 96,1 & 89.7 & 10.3 & 57.8 & 30.8 & 62.6 & - & - \\
\hline ME1 & 95.5 & 90.6 & 9.4 & 44.2 & 25.0 & 65.3 & 2.28 & 2.93 \\
\hline ME2 & 96.1 & 89.1 & 10.9 & 47.8 & 31.4 & 65.0 & 1.63 & 2.15 \\
\hline ME3 & 95.5 & 89.8 & 10.2 & 45.9 & 27.3 & 67.6 & 1.93 & 2.48 \\
\hline ME4 & 95.5 & 90.1 & 9.9 & 49.4 & 26.4 & 65.5 & 2.24 & 2.80 \\
\hline ME5 & 94.7 & 90.9 & 9.1 & 48.8 & 27.6 & 62.4 & 2.01 & 2.54 \\
\hline
\end{tabular}

$\mathrm{DM}=$ dry matter, $\mathrm{OM}=$ organic matter, $\mathrm{A}=$ ash content, $\mathrm{NDF}=$ neutral detergent fiber, $\mathrm{ADF}=$ acid detergent fiber, DIVDM = digestibility in vitro of dry matter.

From our results, it seems that tropical grass-based diets with cassava leaf supplements (a resource accessible to resource poor farmers) have the potential to serve as an important source of cattle feed, particularly during the dry season [43], with low methane production compared to diets based on tropical grasses alone. Whereas the presence of condensed tannins in cassava leaves could form indigestible complexes with protein and thus increase the amino acid requirements of cattle fed with cassava leaf supplements [44], different studies have shown that cassava leaves can safely serve as 
an important source of cattle feed $[45,46]$. Nevertheless, it is clear that further research is required to confirm the mitigation benefits and inform the development of protocols for safe administration to cattle in the tropics.

\subsection{Soil Information for Better Targeting and Improving Resource Use Efficiency}

A total of 21 landscape units were generated for the pilot area and used to link the soil properties data to these units to generate continuous property maps of $\mathrm{pH}$, organic matter (OM), clay, and sand for the topsoil $(0$ to $20 \mathrm{~cm})$ at $90 \mathrm{~m}$ resolution for a study area including three rice growing regions in the Tolima Department, Colombia (Figure 4). All three rice-growing areas showed differences in soil properties, which require dissimilar management strategies to improve resource use efficiency. Although the soil $\mathrm{pH}$ did not vary much within the rice areas, we observed that soils in the study region are generally basic $(\mathrm{pH}>7)$ and that soils in Norte-Meseta have higher $\mathrm{pH}$ than the other two study areas. In Saldaña the areas with $\mathrm{pH}$ greater than 7 increased by 10\% from 1980 to 1997, and, in Norte-Meseta, this change was $15 \%$ for the same period [47]. The Norte-Meseta region also showed a higher soil OM content than the other areas, especially when compared to, which had the lowest OM content. The soils in Saldaña have the lowest sand content, while clay did not show much difference among the three rice growing areas.
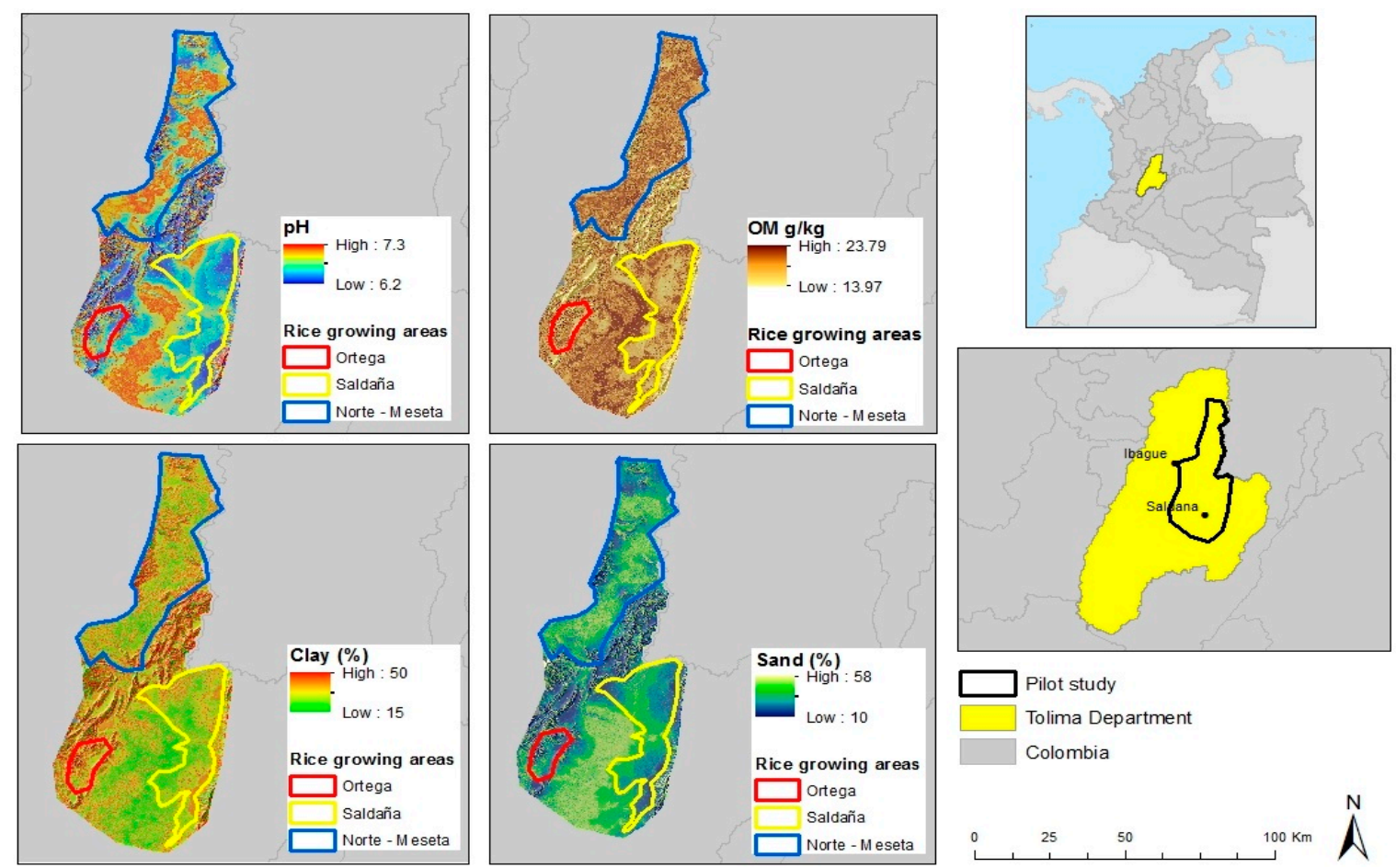

Figure 4. Continuous digital soil maps of $\mathrm{pH}$, organic matter (OM), clay, and sand for a pilot area in the rice-growing region of the Tolima Department, Colombia.

The descriptive statistics and accuracy of the prediction at validation points are presented in Table 3. In general, all the soil properties mapped in the pilot area had different prediction performances, indicating that not all soil properties vary equally in the region. The average values of the prediction were very close to the observed values for soil $\mathrm{pH}$ and sand but smaller for $\mathrm{OM}$ and greater for clay. Comparing the maximum and minimum values of the prediction with the observed values, it is noted that the approach overestimated the minimum values and underestimated the maximum values. On the other hand, when we analyze the accuracy of the prediction, we observe 
that the model performed very well as it showed a general precision of greater than $78 \%$, with errors varying from 5 to $22 \%$, indicating that this approach works well with limited data.

Table 3. Descriptive statistics and accuracy of the prediction of validation points calculated by the Root Mean Square Error Normalized (RMSEn).

\begin{tabular}{cccccccc}
\hline \multirow{2}{*}{ Property } & \multicolumn{3}{c}{ Observed } & \multicolumn{3}{c}{ Predicted } & \multirow{2}{*}{ RMSEn \% } \\
\cline { 2 - 7 } & Average & Maximum & Minimum & Average & Maximum & Minimum & \\
\hline $\mathrm{pH}\left(\mathrm{H}_{2} \mathrm{O}\right)$ & 6.47 & 7.96 & 5.35 & 6.60 & 7.30 & 6.20 & 19 \\
$\mathrm{OM}(\mathrm{g} / \mathrm{kg})$ & 20.9 & 66.6 & 5.1 & 17.4 & 23.8 & 14 & 5 \\
$\mathrm{Clay}(\%)$ & 22 & 85 & 10 & 27 & 50 & 15 & 17 \\
Sand (\%) & 40 & 68 & 2 & 40 & 58 & 10 & 22 \\
\hline
\end{tabular}

OM: Organic matter; RMSEn: Root Mean Square Error normalized.

\subsection{Implementing CSA Practices in CSV of Cauca-Colombia}

The key strategy for implementing the CSV approach is based on combining a triad involving (i) an interested and committed community; (ii) local development practitioners, including local governments and extensionists, whose goals are aligned to supporting communities to address climate challenges in agriculture and food security; and (iii) the technical branch, with scientists and researchers committed to understanding local challenges first and then proposing and co-developing CSA options that address these, considering the context specific conditions. The approach includes a farm-level vulnerability analysis, developed together with rural families, in which major climate risks are identified for each farm. This analysis is used to prioritize the CSA options needed for each farm to address those risks through the formulation of a local adaptation plan.

The CSV process is grounded in having farmers as allies, who decide on what kind of research they consider useful in their territory. They are also part of the designing and implementation process of research activities. Moreover, local youth are involved to increase their knowledge and accelerate their learning towards becoming community experts on CSA practices. The CSV approach is based on the premise that farmers should be able to explain research results generated in their territory and be aware of the implications for their agricultural systems. For example, Cauca CSV farmers now understand and communicate the economic and emission reduction benefits of using organic instead of mineral fertilizer to visitors and other non-CSV farmers. Therefore, the CSV approach enables communities to engage in scaling up and out promising CSA options through local organizations and governments, which goes beyond traditional participatory approaches. Moreover, communities are empowered to determine how to invest official resources allocated to their village, and they are also able to develop project proposals that can support the implementation of their local adaptation plan and continue increasing resilience in their territory.

\subsection{Perspectives}

At the farm level, the major drivers of management practices or new technology adoption include (a) a reduction in production costs, (b) increased productivity, and (c) increased resource use efficiencies (i.e., water). These three components are influenced by interactions between farmers, research, government, and the private sector. In the case of multiple-win management practices such as AWD, which, if done properly, may be associated with a reduction in the total costs of production (depending on water pricing) while maintaining rice yields and reducing GHG emissions, adoption by farmers should be a given [48]. Yet, generally the adoption of AWD by farmers is still limited [49] due to several factors: (a) limited farmer awareness of the technology and its associated benefits; (b) the risk averseness of farmers as AWD can be inherently risky, especially if not executed properly (c) a policy landscape that does not incentivize AWD adoption, i.e., policies related to water pricing; and (d) a lack of evidence of the benefits of AWD under local conditions. 
To achieve wider adoption of AWD, there is a need to focus on better spatial targeting of the management practice by using a combination of soil mapping tools, rice statistics, and climatic data to develop AWD suitability maps [50]. In addition to promoting the efficient use of limited financial resources in promoting AWD, avoiding areas where AWD will not be beneficial is also strategic, as it allows development practitioners to focus on areas where success is more probable and, consequently, to lead to farmers gaining a better appreciation of AWD. In addition, to increase the probability of successful scaling, borrowing from experiences in the Cauca-CSV, there is a need for real, open, and continuous communication between farmers, researchers, and development practitioners.

The adaptation of AWD to suit local socio-economic and cultural contexts is necessary to increase adoption rates. For instance, as our results suggest that weeding is an activity mostly done by women, AWD should be adapted to reduce the time dedicated to weeding by apply the drying cycles after full canopy cover has been attained so that weeds are easily outcompeted by the rice due to a lack of light within the canopy [51]. Therefore, we believe that, in addition to environmental sustainability, targeting the correct actors and not burdening the farmers with excess work to implement the technology are crucial factors. Finally, from a policy perspective, to support the adoption of AWD, water pricing mechanisms that incentivize farm-level water savings are necessary.

In the case of using cassava leaves to supplement cattle diets, a major challenge is related to increasing farmer awareness of this technological option and its benefits. CIAT and partners are currently testing the utility of this technology by conducting measurements on $\mathrm{CH}_{4}$ emissions from cattle fed diets including cassava and BH mixtures. However, lower proportions $(<20 \%)$ of leaves are being used to avoid huge negative effects on feed digestion. Moreover, to avoid the misuse of the technology, there is need to use data from in vivo measurements to design protocols with clear instructions on how to benefit from the technology. Interestingly, previous studies suggest that the pruning of cassava several days or weeks prior to harvest increases the root quality and the shelf life [52]. This implies that pruning cassava leaves to use as a cattle feed supplements is a multiple-win strategy. However, more research is needed to understand who in the household would be responsible for pruning and processing cassava leaves and to develop an in-depth understanding of the gender roles along the cattle and cassava value chains.

Acknowledgments: Part of this work was implemented as part of the as well as the LivestockPlus project and the Latin America climate change mitigation network (LAMNET), which are financed through the CGIAR Research Program on Climate Change, Agriculture and Food Security (CCAFS), which is carried out with support from CGIAR Fund Donors and through bilateral funding agreements. For details, please visit https://ccafs.cgiar.org/donors. Other parts of the work presented here were funded through the Climate and Clean Air Coalition (CCAC); the Colombian Ministry of Agriculture and rural development (MADR); FEDEARROZ; and the Japanese government, through the Science and Technology Research partnership for sustainable development (SATREPS) programme. The views expressed in this document cannot be taken to reflect the official opinions of these organizations.

Author Contributions: As this article contains data and information from several projects, authors participated in the designing, experimentation, data analysis and writing in the four broad areas: Livestock, Rice, Gender and the Climate Smart Villages. Specifically, author contributions were as follows: Livestock-N.C., J.N., J.A., L.A.B.L-L, M.P., L.S., D.E., J.Ta, L.M., A.P., A.Z., N.L., C.A., I.R., R.B.; Rice-N.C., C.T., M.K., P.C., F.C., M.I., M.D.S., I.A., My.G., E.G., S.J., G.L.; Gender-J.Tw. Ma.G., D.A.; Climate smart village-N.C., L.A., S.L., D.M.-B., and A.M.L.

Conflicts of Interest: The authors declare no conflicts of interest.

\section{References}

1. FAO. Climate-Smart Agriculture Sourcebook Executive Summary; FAO: Rome, Italy, 2013. Available online: http:/ / www.fao.org/3/ai3325e.pdf (accessed on 20 April 2017).

2. Lipper, L.; Thornton, P.; Campbell, B.M.; Baedeker, T.; Braimoh, A.; Bwalya, M.; Caron, P.; Cattaneo, A.; Garrity, D.; Henry, K.; et al. Climate-Smart Agriculture for Food Security. Nat. Clim. Chang. 2014, 4, 1068-1072. [CrossRef] 
3. Huyer, S.; Twyman, J.; Koningstein, M.; Ashby, J. Supporting Women Farmers in a Changing Climate: Five Policy Brief Lessons; Policy Brief No. 10. CCAFS; Research Program on Climate Change, Agriculture and Food Security (CCAFS): Frederiksberg, Denmark, 2015.

4. Bernard, M.A.; Urbina, M.A.; Corrales, R.; Der Hoek, R.; Ojango, J.M. The silent cattle breeders in central Nicaragua. In A Different Kettle of Fish? Gender Integration in Livestock and Fish Research; Pyburn, R., van Eerdewijk, A., Eds.; LM Publishers: Volendam, The Netherlands, 2016.

5. World Bank Group. World Bank Group Gender Strategy (FY16-23): Gender Equality, Poverty Reduction and Inclusive Growth; License: CC BY 3.0 IGO; World Bank: Washington, DC, USA, 2015; Available online: https:/ / openknowledge.worldbank.org/handle/10986/23425 (accessed on 21 April 2017).

6. Rao, I.; Peters, M.; Castro, A.; Schultze, R.; White, D.; Fisher, M.; Miles, J.; Lascano, C.; Blummel, M.; Bungenstab, D.; et al. LivestockPlus-The sustainable intensification of forage - based agricultural systems to improve livelihoods and ecosystem services in the tropics. Trop. Grassl. Forrajes Tropicales 2015, 3, 59-82. [CrossRef]

7. Lascano, C.E. Managing the grazing resource for animal production in savannas of tropical America. Trop. Grassl. 1991, 25, 66-72.

8. $\quad$ Fisher, M.J.; Rao, I.M.; Ayarza, M.A.; Lascano, C.E.; Sanz, J.I.; Thomas, R.J.; Vera, R.R. Carbon storage by introduced deep-rooted grasses in the South American savannas. Nature 1994, 371, 236-238. [CrossRef]

9. Byrnes, R.C.; Núñez, J.; Arenas, L.; Rao, I.; Trujillo, C.; Alvarez, C.; Arango, J.; Rasche, F.; Chirinda, N. Biological nitrification inhibition by Brachiaria grass mitigates soil nitrous oxide emission from bovine urine patches. Soil Biol. Biochem. 2017, 107, 156-163. [CrossRef]

10. Subbarao, G.V.; Nakahara, K.; Hurtado, M.D.P.; Ono, H.; Moreta, D.E.; Salcedo, A.F.; Yoshihashi, A.T.; Ishikawa, T.; Ishitani, M.; Ohnishi-Kameyama, M.; et al. Evidence for biological nitrification inhibition in Brachiaria pastures. Proc. Natl. Acad. Sci. USA 2009, 106, 17302-17307. [CrossRef] [PubMed]

11. Kamke, J.; Kittelmann, S.; Soni, P.; Li, Y.; Tavendale, M.; Ganesh, S.; Attwood, G.T. Rumen metagenome and metatranscriptome analyses of low methane yield sheep reveals a Sharpea-enriched microbiome characterised by lactic acid formation and utilisation. Microbiome 2016, 4, 56. [CrossRef] [PubMed]

12. FEDEARROZ. The rice sector in Colombia. In Proceedings of the 3rd Meeting of the Americas Sub-Group of Paddy Rice Research (PRRG) of Global Research Alliance (GRA), Stuttgart, AR, USA, 13-15 July 2016.

13. Adhya, T.K.; Linquist, B.; Searchinger, T.; Wassmann, R.; Yan, X. Wetting and drying: Reducing greenhouse emissions and saving water from rice production. In Working Paper, Installment 8 of Creating a Sustainable Food Future; World Resources Institute: Washington, DC, USA, 2014.

14. Da Silva, M.; Naves, M.L.; Owens, P.R.; Curi, N.; Oliveira, A.; Moreira, B. Predicting Runoff Risks by Digital Soil Mapping. Rev. Bras. Ciênc. Solo 2016, 40,1-11. [CrossRef]

15. CCAFS. Climate-Smart Villages. In An AR4D Approach to Scale up Climate-Smart Agriculture; CGIAR Research Program on Climate Change, Agriculture and Food Security (CCAFS): Copenhagen, Denmark, 2016; Available online: www.ccafs.cgiar.org (accessed on 10 April 2017).

16. Arora, D.; Arango, J.; Burkart, S.; Chirinda, N.; Twyman, J. Gender [Im]balance in Productive and Reproductive Labor among Livestock Producers in Colombia: Implications for Climate Change Responses; CCAFS Info Note; CGIAR Research Program on Climate Change, Agriculture and Food Security (CCAFS): Copenhagen, Denmark, 2017.

17. Van Soest, P.J.; Robertson, J.B.; Lewis, B.A. Methods for Dietary Fiber, Neutral Detergent Fiber, and Nonstarch Polysaccharides in Relation to Animal Nutrition. J. Dairy Sci. 1991, 74, 3583-3597. [CrossRef]

18. Association of Official Analytical Chemists (AOAC). Official Analytical Chemists (AOAC). Official Method 942.05. Determination of Ash in Animal Feed. In Official Methods of Analysis of AOAC International, 18th ed.; Association of Official Analytical Chemists (AOAC): Gaithersburg, MD, USA, 2005; p. 8.

19. Theodorou, M.K.; Williams, B.A.; Dhanoa, M.S.; McAllan, A.B.; France, J. A simple gas production method using a pressure transducer to determine the fermentation kinetics of ruminant feeds. Anim. Feed Sci. Technol. 1994, 48, 185-197. [CrossRef]

20. IGAC. Sistema de Información Geográfico Para La Planeación y el Ordenamiento Territorial. Available online: http://sigotn.igac.gov.co/sigotn/frames_pagina.aspx (accessed on 20 April 2017).

21. Jasiewicz, J.; Stepinski, T.F. Geomorphons-A pattern recognition approach to classification and mapping of landforms. Geomorphology 2013, 182, 147-156. [CrossRef] 
22. Zhu, A.X.; Hudson, B.; Burt, J.; Lubich, K.; Simonson, D. Soil Mapping Using GIS, Expert Knowledge, and Fuzzy Logic. Soil Sci. Soc. Am. J. 2001, 65, 1463-1472. [CrossRef]

23. R Core Team. R: A language and environment for statistical computing. In $R$ Foundation for Statistical Computing; Vienna, Austria, 2012; ISBN 3-900051-07-0. Available online: http://www.R-project.org/ (accessed on 15 March 2017).

24. Di Rienzo, J.A.; Casanoves, F.; Balzarini, M.G.; Gonzalez, L.; Tablada, M.; Robledo, C.W. InfoStat Versión 2012 Software; Grupo InfoStat, FCA, Universidad Nacional de Córdoba: Córdoba, Argentina, 2012.

25. Ambler, K.; Doss, C.; Kieran, C.; Passarelli, S. He Says, She Says: Exploring Patterns of Spousal Agreement in Bangladesh, 01616; International Food Policy Research Institute: Washington, DC, USA, 2017.

26. Beauchemin, K.A.; McAllister, T.A.; McGinn, S.M. Dietary mitigation of enteric methane from cattle. CAB Rev. Perspect. Agric. Vet. Sci. Nutr. Nat. Resour. 2009, 4, 1-18. [CrossRef]

27. Figueiredo, P.; Perkins, P.E. Women and water management in times of climate change: Participatory and inclusive process. J. Clean. Prod. 2013, 60, 188-194.

28. Garcia, M.A.; Katto, M.C.; Twyman, J.; LaHue, G.; Chirinda, N. How might the gender roles affect the implementation of a new water-saving technique for Colombian rice production? In Descriptive Report of Gender Dimensions in Colombian Rice Production; CIAT: Cali, Colombia, 2016.

29. Linquist, B.A.; Anders, M.M.; Adviento-Borbe, M.A.A.; Chaney, R.; Nalley, L.L.; da Rosa, E.F.F.; van Kessel, C. Reducing greenhouse gas emissions, water use, and grain arsenic levels in rice systems. Glob. Chang. Biol. 2015, 21, 407-417. [CrossRef] [PubMed]

30. Linquist, B.A.; van Groenigen, K.J.; Adviento-Borbe, M.A.; Pittelkow, C.M.; van Kessel, C. An agronomic assessment of greenhouse gas emissions from major cereal crops. Glob. Chang. Biol. 2012, 18, 194-209. [CrossRef]

31. Cicerone, R.J.; Delwiche, C.C.; Tyler, S.C.; Zimmerman, P.R. Methane emissions from California rice paddies with varied treatments. Glob. Biogeochem. Cycles 1992, 6, 233-248. [CrossRef]

32. Mitra, A.P. Greenhouse Gas Emission in India; Scientific Report No. 20; Methane Campaign Council of Scientific and Industrial Research, and Ministry of Environment and Forest: New Delhi, India, 1992.

33. Wang, Z.P.; Lindau, C.W.; Delaune, R.D.; Patrick, W.H. Methane emission and entrapment in flooded rice soils as affected by soil properties. Biol. Fertility Soils 1993, 16, 163-168. [CrossRef]

34. Thawda, K.W.; Ryoko, N.; Aye Thida, W.; Yu, S.; Kok, T.; Takashi, M. Effects of water saving irrigation and rice variety on greenhouse gas emissions and water use efficiency in a paddy field fertilized with anaerobically digested pig slurry. Paddy Water Environ. 2015, 13, 51-60.

35. Katayanagi, K.; Furukawa, Y.; Fumoto, T.; Hosen, Y. Validation of the DNDC-rice model by using $\mathrm{CH}_{4}$ and $\mathrm{N}_{2} \mathrm{O}$ flux data from rice cultivated in pots under alternate wetting and drying irrigation management. Soil Sci. Plant Nutr. 2012, 58, 360-372. [CrossRef]

36. IPCC. Climate Change 2013. In The Physical Science Basis Working Group I Contribution to the Fifth Assessment Report of the Intergovernmental Panel on Climate Change; Stocker, T.F., Qin, D., Plattner, G.K., Eds.; Cambridge University Press: Cambridge, UK; New York, NY, USA, 2013.

37. Hess, H.D.; Tiemann, T.T.; Noto, F.; Carulla, J.E.; Kreuzer, M. Strategic Use of Tannins as Means to Limit Methane Emission from Ruminant Livestock. In Proceedings of the 2nd International Conference on Greenhouse Gases and Animal Agriculture, Zurich, Switzerland, 20-24 September 2006; Volume 1293, pp. 164-167.

38. Tan, H.Y.; Sieo, C.C.; Abdullah, N.; Liang, J.B.; Huang, X.D.; Ho, Y.W. Effects of condensed tannins from Leucaena on methane production, rumen fermentation and populations of methanogens and protozoa in vitro. Anim. Feed Sci. Technol. 2011, 169, 185-193. [CrossRef]

39. Tiemann, T.T.; Lascano, C.E.; Wettstein, H.R.; Mayer, A.C.; Kreuzer, M.; Hess, H.D. Effect of the tropical tannin-rich shrub legumes Calliandra calothyrsus and Flemingia macrophylla on methane emission and nitrogen and energy balance in growing lambs. Animal 2008, 2, 790-799. [CrossRef] [PubMed]

40. Kume, S. Establishment of Profitable Dairy Farming System on Control of Methane Production in Hokkaido Region. In Greenhouse Gases and Animal Agriculture; Takahashi, J., Young, B.A., Eds.; Elsevier: Obihiro, Japan, 2002; pp. 87-94.

41. Elghandoura, M.M.; Vázqueza, J.C.; Salema, A.Z.; Kholifb, A.E.; Ciprianoc, M.M.; Camachoc, L.M.; Márquezd, O. In vitro gas and methane production of two mixed rations influenced by three different cultures of Saccharomyces cerevisiae. J. Appl. Anim. Res. 2017, 45, 389-395. [CrossRef] 
42. Jayanegara, A.; Togtokhbayar, N.; Makkar, H.P.S.; Becker, K. Tannins determined by various methods as predictors of methane production reduction potential of plants by an in vitro rumen fermentation system. Anim. Feed Sci. Technol. 2009, 150, 230-237. [CrossRef]

43. Wanapat, M. Manipulation of Cassava Cultivation and Utilization to Improve Protein to Energy Biomass for Livestock Feeding in the Tropics. Asian-Australasian. J. Anim. Sci. 2003, 16, 463-472.

44. Reed, J.D.; McDowell, R.E.; Van Soest, P.J.; Horvath, P.J. Condensed tannins: A factor limiting the use of cassava forage. J. Sci. Food Agric. 1982, 33, 213-220. [CrossRef]

45. Henderson, L. Cassava: An economically viable animal feed: Feeds \& grazing. Stockfarm 2015, 5, 32-33.

46. Lukuyu, B.; Okike, I.; Duncan, A.J.; Beveridge, M.; Blummel, M. Use of Cassava in Livestock and Aquaculture Feeding Programs; International Livestock Research Institute (ILRI): Nairobi, Kenya, 2014; Volume 25.

47. Federación Nacional de Arroceros (FEDEARROZ). Manejo y Conservación de Suelos Para la Producción de Arroz en Colombia; FEDEARROZ: Bogotá, Colombia, 2000; p. 78.

48. Yang, J.; Zhou, Q.; Zhang, J. Moderate wetting and drying increases rice yield and reduces water use, grain arsenic level, and methane emission. Crop J. 2016, 5, 151-158. [CrossRef]

49. Mushtaq, S.; Khan, S.; Hafeez, N.; Hanjra, M.A. Does reliability of water re-sources matter in the adoption of water-saving irrigation practices? A case study in the Zhanghe irrigation system, China. Water Policy 2009, 11, 661-679. [CrossRef]

50. Nelson, A.; Wassmann, R.; Sander, B.O.; Palao, L.K. Climate-Determined Suitability of the Water Saving Technology 'Alternate Wetting and Drying' in Rice Systems: A Scalable Methodology demonstrated for a Province in the Philippines. PLoS ONE 2015, 10, e0145268. [CrossRef] [PubMed]

51. LaHue, G.T.; Chaney, R.L.; Adviento-Borbe, M.A.; Linquist, B.A. Alternate wetting and drying in high yielding direct-seeded rice systems accomplishes environmental and agronomic objectives. Agric. Ecosyst. Environ. 2016, 229, 30-39. [CrossRef]

52. Wenham, J.E. Post-Harvest Deterioration of Cassava. A Biotechnology Perspective; Food and Agriculture Organization (FAO): Rome, Italy, 1995; p. 116.

(C) 2017 by the authors. Licensee MDPI, Basel, Switzerland. This article is an open access article distributed under the terms and conditions of the Creative Commons Attribution (CC BY) license (http:/ / creativecommons.org/licenses/by/4.0/). 